\title{
PENGEMBANGAN BAHAN AJAR MULTILINGUAL BERBASIS KONTEN DAN KONTEKS BUDAYA LOKAL ETNIS NGADA PADA TEMA DIRIKU UNTUK SISWA KELAS I SEKOLAH DASAR
}

\author{
Maria Klarita Mutiara Wini ${ }^{1}$, Dek Ngurah Laba Laksana ${ }^{2}$ dan Ermelinda Yosefa Awe ${ }^{3}$ \\ Program Studi Pendidikan Guru Sekolah Dasar, STKIP Citra Bakti \\ Jalan Trans Bajawa-Ende, Kecamatan Golewa, Kabupaten Ngada, NTT \\ 1mariaklaritamutiarawini@gmail.com 2laba.laksana@citrabakti.ac.id 3ermelindayosefaawe8@gmail.com
}

\begin{abstract}
Abstrak
Penelitian pengembangan ini bertujuan untuk: (1) menghasilkan bahan ajar multilingual berbasis konten dan konteks budaya lokal etnis Ngada pada tema diriku yang sesuai dengan karakteristik siswa kelas I Sekolah Dasar, (2) mengetahui kualitas hasil uji produk pengembangan bahan ajar multilingual berbasis budaya lokal etnis Ngada pada tema diriku untuk siswa Sekolah Dasar kelas I. Untuk bahan ajar ini menggunakan dua bahasa yaitu bahasa Indonesia dan bahasa daerah Bajawa. Bahan ajar multilingual berbasis budaya lokal ini dikembangkan menggunakan model ADDIE (analyze, design, development, implementation dan evaluation). Untuk menghasilkan produk bahan ajar yang baik peneliti melakukan uji coba kepada masing-masing ahli yaitu: ahli konten/ materi, ahli bahasa Indonesia, ahli bahasa daerah dan ahli desain. Untuk mengetahui kualitas produk peneliti melakukan uji coba dengan menyerahkan lembar penilaian kuisioner kepada ahli untuk diberi penilaian. Untuk skala penialian 5-1. Berdasarkan hasil uji coba ahli materi/ konten kualitas/mutu produk mendapatkan kriteria "sangat baik" dengan skor rata-rata 4,2. Berdasarkan hasil uji coba ahli bahasa Indonesia kualitas/ mutu produk mendapatkan kriteria "sangat baik" dengan skor rata-rata 4,8. Berdasarkan hasil uji coba ahli bahasa daerah kualitas/ mutu produk mendapatkan kriteria“baik" dengan skor rata-rata 3,7. Berdasarkan hasil uji coba ahli desain kualitas/ mutu produk mendapatkan kriteria"baik" dengan skor rata-rata 3,90. Berdasarkan hasil uji coba tersebut dapat disimpulkan bahwa bahan ajar multilingual berbasis konten dan konteks budaya lokal Ngada layak untuk digunakan.
\end{abstract}

\begin{abstract}
This development research aims to (1) produce multilingualisme teaching materials based on content and local cultural context of the ngada ethnic group on the caharacteristics of grade $i$ elementary school students, (2) determine the quality of the product test results of the development of multilingualisme teaching materials based on local culture of the Ngada ethnic group on the theme of me for grade I elementary school students. For this teaching material using two languages, is Indonesian language and Bajawa regional language multilingualisme teaching materials based on local cultural were developed using the ADDIE model (analyze, design, development, implementation and evaluation). To be good teaching material products the researcher conducted trials on each expect to content/ material experts. Indonesia language exprest regional language experts and design experts. To determine the quality of the product, the researcher conducted a trial by submitting a questionnaire assessment sheet to the expart to be given on assessment. For the 5-1 assessment scale. Based on the test results of the material/ content expart, the quality/ product quality got the criteria of "Very Good", with an average score of 4.2. Based on the test results of the local linguist the product quality got the "Good" criteria with an average score of 3.7. Based the results of the test, the design expert, the quality/ product quality got the "Good" criteria with an average score of 3. 90. Based on the result of these trials, it can be conclude that the multilingaulisme teaching materials based on contex and the local cultural context of Ngada are feasible to use.
\end{abstract}

Keywords: Development of Learning Materials, Lokal Culture of Ngada Ethnic 


\section{PENDAHULUAN}

Kemampuan dalam mengembangkan bahan ajar sendiri merupakan perwujudan dari kompetensi pedagogik yang menjadi salah satu kemampuan yang dimiliki guru. Hal ini sama dengan Undang-Undang Sisdiknas Nomor 20 Tahun 2003 dalam Standar Isi yang menyatakan bahwa suatu proses dalam pembelajaran, guru harus mampu menyusun bahan ajar yang kontekstual sesuai dengan kebutuhan dan lingkungan masyarakat setempat (Depdiknas, 2003). Bahan ajar yang dikembangkan juga dinilai harus mampu meningkatkan semangat belajar dan motivasi belajar peserta didik sehingga tercapainya tujuan pembelajaran yang ditetapkan.

Bahan ajar cetak dibuat oleh pemerintah belum mengedepankan budaya lokal masyarakat dan unsur lingkungan setempat. Bahan ajar yang digunakan dalam proses pembelajaran sangat penting untuk di tambahkan dengan unsur budaya lokal. Mereka akan lebih memahami materi karena karakteristik siswa Sekolah Dasar lebih senang belajar sesuai dengan kenyataan. Kondisi inilah yang mengharuskan guru untuk mengembangkan bahan ajar yang sesuai dengan konteks budaya lokal daerah tempat tinggal. Bahan ajar yang dimaksud dianggap mengakomodir adalah bahan ajar berbasis budaya lokal Ngada.

Budaya lokal yang mau dikembangkan adalah budaya lokal etnis Ngada. Di Kabupaten Ngada ada tiga etnis yaitu: etnis Ngada, etnis Riung dan etnis Soa. Bahan ajar yang akan dikembangkan adalah bahan ajar berbasis budaya lokal etnis Ngada khususnya di lokasi Kecamatan Golewa.

Multilingual adalah sistem pendidikan yang menggunakan dua bahasa atau lebih dari dua bahasa.sedangkan Bilingual merupakan sistem pendidikan yang menggunakan dua bahasa. Bahasa yang digunakan adalah bahasa Indonesia dan bahasa daerah Bajawa. multilingual adalah kemampuan seseorang dalam berkomunikasi menggunakan dua bahasa sekaligus. Dalam dunia pendidikan perlu juga diterapkan multilingual dengan tujuan memberikan pengalaman baru kepada siswa, merangsang kemampuan berpikir dan meningkatkan kemampuan komunikasi dengan lawan bicara. multilingual sangat cocok diterapkan di sekolah dasar dengan tujuan membelajarkan dua bahasa sekaligus kepada peserta didik, sehingga bermanfaat juga untuk pembelajaran yang lebih lanjut yang harus peserta didik pelajari.

Elvianti (2015) menyebutkan bahwa budaya adalah sesuatu yang sangat akrab dengan lingkungan peserta didik, sehingga diharapkan akan menjadi pendorong dalam peningkatan hasil belajar peserta didik. Pentingnya pendidikan tentang budaya yang diterapkan dalam pembelajaran dan dituangkan dalam buku ajar tersebut juga dipicu atas penanaman nilai-nilai budaya lokal. Pembelajaran berbasis budaya lokal menjadi sebuah media bagi siswa untuk mentransformasikan hasil observasi mereka ke dalam bentuk prinsip-prinsip yang kreatif tentang alam. Dengan demikian, melalui pembelajaran berbasis budaya, siswa bukan sekedar meniru dan atau menerima saja informasi yang diberikan, tetapi siswa menciptakan makna dan pemahaman dari informasi yang didapatnya. Demikian juga, pembelajaran berbasis budaya bukan sekedar menstransfer atau menyampaikan budaya atau perwujudan budaya, tetapi menggunakan budaya untuk menjadikan siswa mampu menciptakan makna, menembus batas imajinasi, dan kreativitas untuk mencapai pemahaman yang mendalam tentang materi subyek yang dipelajarinya.

Unsur budaya lokal ini cocok dimasukan ke dalam bahan ajar, khususnya untuk di Sekolah Dasar. Namun, bahan ajar yang sekarang digunakan di sekolah-sekolah masih menggunakan bahan ajar cetak yang disediakan oleh pemerintah yang mungkin kurang mengedepankan unsur budaya lokal masyarakat setempat. Dengan menerapkan multilingual dalam proses pembelajaran. Sekolah-sekolah sebagian besar belum mengintegrasikan multilingual dalam proses pembelajaran, minimnya usaha guru dalam mengaitkan materi pembelajaran dan konteks budaya lokal, kemampuan nalar siswa masih sangat minim, bahan 
ajar cetak ini juga dinilai kurang menarik dan membuat siswa mudah jenuh dalam membacanya. Oleh karena itu, guru perlu menyusun bahan ajar yang lebih menarik dan bersifat kontekstual. Bahan ajar yang cocok digunakan agar siswa tidak merasa jenuh dalam mengikuti proses pembelajaran adalah bahan ajar cetak multilingual yang berbasis konten dan konteks budaya lokal, karena bahan ajar cetak multilingual ini memuat unsur teks, dan gambar yang mengacu pada konten dan konteks budaya lokal. Pemanfaatan bahan ajar multilingual dalam pembelajaran mampu meningkatkan motivasi dan semangat belajar siswa.

Sesuai dengan latar belakang yang dipaparkan di atas, maka tujuan penelitian ini adalah sebagai berikut: 1) untuk menghasilkan bahan ajar multilingual berbasis budaya lokal etnis Ngada pada tema I Diriku yang sesuai dengan karakteristik siswa kelas I Sekolah Dasar, 2) untuk mengetahui kualitas hasil uji produk pengembangan bahan ajar multilingual berbasis budaya lokal etnis Ngada pada tema I Diriku untuk siswa sekolah dasar kelas I.

Produk yang dihasilkan berupa bahan ajar dengan spesifikasi adalah sebagai berikut: 1) wujud fisik dari produk yang dihasilkan dalam pengembangan ini adalah bahan ajar cetak, 2) bahan ajar multilingual yang dikembangkan peneliti berisi semua materi yang ada di kelas I Sekolah Dasar pada tema diriku, 3) materi yang dikemas dalam bahan ajar cetak ini diintegrasikan dengan konteks budaya lokal Ngada, 4) bahan ajar cetak ini diperuntukkan bagi siswa sebagai sumber belajar tambahan, 5) bahan ajar cetak multilingual ini membantu siswa kelas I Sekolah Dasar dalam memahami materi pada tema diriku, 6) bahan ajar multilingual ini memuat unsur teks dan gambar, 7) bahan ajar cetak multilingual ini juga dilengkapi dengan soallatihan yang dapat digunakan untuk mengukur pemahaman siswa dalam belajar, 8) terdapat panduan penggunaan bahan ajar cetak multilingual, yang dapat memudahkan siswa dalam menggunakan bahan ajar cetak multilingual ini.

Pengembangan bahan ajar multilingual berbasis konten dan konteks budaya lokal etnis Ngada ini mengacu pada beberapa asumsi adalah sebagai berikut: 1) pengembangan bahan ajar multilingual berbasis konten dan konteks budaya lokal etnis Ngada dapat membantu dan mempermudah siswa Sekolah Dasar kelas I dalam memahami materi pada tema diriku, 2) dengan menggunakan bahan ajar multilingual berbasis konten dan konteks budaya lokal etnis Ngada ini dapat meningkatkan semangat dan motivasi siswa dalam mengikuti pembelajaran, 3) minimnya bahan ajar multilingual yang diintegrasikan dengan budaya lokal Ngada. Adapun keterbatasan pengembangan bahan ajar multilingual berbasis konten dan konteks budaya lokal etnis Ngada ini adalah sebagai berikut: 1) pengembangan bahan ajar multilingual ini hanya menggunakan dua bahasa yaitu bahasa Indonesia dan bahasa daerah Bajawa, 2) pengembangan bahan ajar multilingual ini hanya terbatas pada uji ahli karena adanya pendemi covid-19,3) pengembangan bahan ajar multilingual ini terbatas pada materi di kelas 1 Sekolah Dasar pada tema diriku, 4) pengembangan bahan ajar ini mengacu pada model pengembangan ADDIE, 5) instrumen dalam pengembangan ini hanya berupa angket saja..

\section{METODE}

Jenis penelitian yang akan dilakukan dalam penelitian ini adalah penelitian pengembangan. Pengembangan bahan ajar cetak multilingual ini menerapkan model pengembangan ADDIE. Anglada (2007) menguraikan bahwa model penelitian ini mempunyai lima tahapan adalah sebagai berikut: (1) analyze, (2) design, (3) development, (4) implementation, dan (5) evaluation.

Produk yang dihasilkan berupa bahan ajar cetak (multilingual) berbasis konten dan konteks budaya lokal etnis Ngada pada tema diriku di kelas I. Uji coba produk ini menggunakan instrumen dalam bentuk angket yang telah disusun. Instrumen yang berupa angket dinilai oleh ahli konten/materi pada kelayakan isi, ahli desain pada kelayakan desain pengembangan bahan ajar, ahli bahasa pada kesesuaian penggunaan bahasa. 
Adapun beberapa metode yang digunakan dalam proses pengumpulan data yaitu metode observasi, metode wawancara, metode pencatatan dokumen dan metode tes. Instrumen pengumpulan data dalam penelitian pengembangan bahan ajar cetak ini adalah berupa angket yang mengacu pada penilaian Badan Standarisasi Nasional Pendidikan (BNSP), yang terdiri atas komponen isi dan kegrafikan. Instrumen dari BSNP digunakan karena pada dasarnya instrumen penilaian BSNP digunakan untuk penilaian bahan ajar cetak. Metode analisis data yang dihimpun dari penelitian ini dianalisis secara deskriptif.

\section{HASIL DAN PEMBAHASAN Hasil Pengembangan}

1. Tahap Analisis (Analyze)

Salah satu aspek yang dianalisis pada tahap ini adalah kurikulum. Peneliti mengkaji Kompetensi Dasar dalam pencapaian pembelajaran Permendikbud Nomor 26 Tahun 2016.

2. Tahap Desain (Design)

Dalam bahan ajar diperlukan tahapan desain untuk menentukan unsur-unsur seperti penyusunan jaring-jaring tema, mengumpulkan referensi yang di butuhkan untuk mengambangkan bahan ajar, dan draf bahan ajar. Peneliti juga mencari dan mengumpulkan gambar-gambar yang yang bersangkutan dengan materi ajar yang di kembangkan. Gambar yang dihasilkan berbasis budaya lokal Ngada dan bersifat kontekstual.

3. Tahap Pengembangan (Development)

Pada tahap pengembangan ini adalah tahap realisasi/ penguaktualan bahan ajar. Hasil pengembangan bahan ajar multilingual berbasis budaya lokal ini adalah sebagai berikut.

Tabel 1 Produk Bahan Ajar Hasil Pengembangan

\begin{tabular}{|c|c|c|}
\hline No & $\begin{array}{l}\text { Bagian Bahan } \\
\text { Ajar }\end{array}$ & Deskripsi Hasil Pengembangan \\
\hline 1 & Sampul Depan & $\begin{array}{l}\text { Sampul depan merupakan tampilan awal dan tampilan akhir dari buku } \\
\text { tematik yang dikembangkan. }\end{array}$ \\
\hline 2 & Kata Pengantar & $\begin{array}{l}\text { Kata pengantar dibuat secara sederhana dan bertujuan untuk } \\
\text { menyampaikan ucapan rasa syukur dan terima kasih. }\end{array}$ \\
\hline 3 & Daftar Isi & $\begin{array}{l}\text { Bahan ajar multilingual yang dikembangkan terdapat daftar isi yag dibuat } \\
\text { untuk memudahkan pembaca untuk menentukan sub tema dan halaman } \\
\text { berapa yang akan dipelajarai. }\end{array}$ \\
\hline 4 & Jaringan Tema & $\begin{array}{l}\text { Jaringan tema yang dikembangkan adalah tema } 1 \text { "Diriku" Siswa Sekolah } \\
\text { Dasar Kelas I. Jaringan tema yang terdapat dalam bahan ajar ini berisi } \\
\text { tentang beberapa mata pelajaran seperti mata pelajaran Bahasa Indonesia, } \\
\text { mata pelajaran Matematika, mata pelajaran PPKn dan mata pelajaran } \\
\text { SBdP dilengkapi dengan kompetensi dasar yang akan dicapai oleh siswa. }\end{array}$ \\
\hline \multirow[t]{3}{*}{5} & Isi Buku & $\begin{array}{l}\text { Materi ajar yang dikembangkan dalam bahan ajar multilingual adalah } \\
\text { materi terdapat dalam tema "Diriku" tema } 1 \text { kelas I SD. Tema ini terdiri } \\
\text { atas } 4 \text { sub tema yaitu aku dan teman baru, tubuhku, aku merawat tubuhku, } \\
\text { dan aku istimewa. Setiap sub tema terdiri atas } 6 \text { (enam) pembelajaraan } \\
\text { yang akan diajarkan kepada peseta didik dalam proses pembelajaran. }\end{array}$ \\
\hline & & $\begin{array}{l}\text { Fokus pembelajaran dalam tema ini adalah Bahasa Indonesia, } \\
\text { Matematika, PPKn dan SBdP. Materi-materi yang dikembangkan } \\
\text { diintegrasikan dengan konteks budaya lokal masyarakat Ngada. }\end{array}$ \\
\hline & & $\begin{array}{l}\text { Bahan ajar yang telah dikembangkan juga terdapat gambar-gambar yang } \\
\text { sesuai dengan materi yang akan diajarkan seperti permainan kelereng } \\
\text { (dhara), gambar tarian (ja'i). adapun berbagai kegiatan yang ada dalam } \\
\text { tema ini dibagi dalam beberapa kegiatan belajar yaitu kegiatan ayo } \\
\text { mengamati, ayo berlatih, ayo membaca, ayo menulis, ayo berkreasi, ayo }\end{array}$ \\
\hline
\end{tabular}




\begin{tabular}{|c|c|c|}
\hline No & $\begin{array}{c}\text { Bagian Bahan } \\
\text { Ajar }\end{array}$ & Deskripsi Hasil Pengembangan \\
\hline & & menari, ayo mencoba dan ayo bermain peran. \\
\hline & & $\begin{array}{l}\text { Sasaran dari buku ini adalah memberikan pengetahuan kepada siswa } \\
\text { mengenai materi pelajaran yang berkaitan dengan konteks budaya lokal } \\
\text { masyarakat Ngada. Selain itu juga, bahan ajar multilingual ini disusun } \\
\text { agar siswa mendapat gambaran yang jelas dan rinci dalam melaksanakan } \\
\text { proses pembelajaran berbasis konten dan konteks budaya lokal } \\
\text { masyarakat Ngada }\end{array}$ \\
\hline 6 & Daftar Pustaka & $\begin{array}{l}\text { Daftar pustaka berisi sumber-sumber penyelesaian bahan ajar } \\
\text { multilingual. Materi-materi yang digunakan untuk menyusun bahan ajar } \\
\text { diambil dari buku siswa dan buku guru kelas I tema "Diriku". }\end{array}$ \\
\hline
\end{tabular}

Bagian bagian hasil pengembangan disajikan dalam bentuk gambar seperti yang disajikan pada Gambar 1. Gambar yang disajikan antara lain adalah sampul depan buku, salah satu bagian yang terdapat materi pembelajaran, dan bagian yang terdapat soal soal latihan.
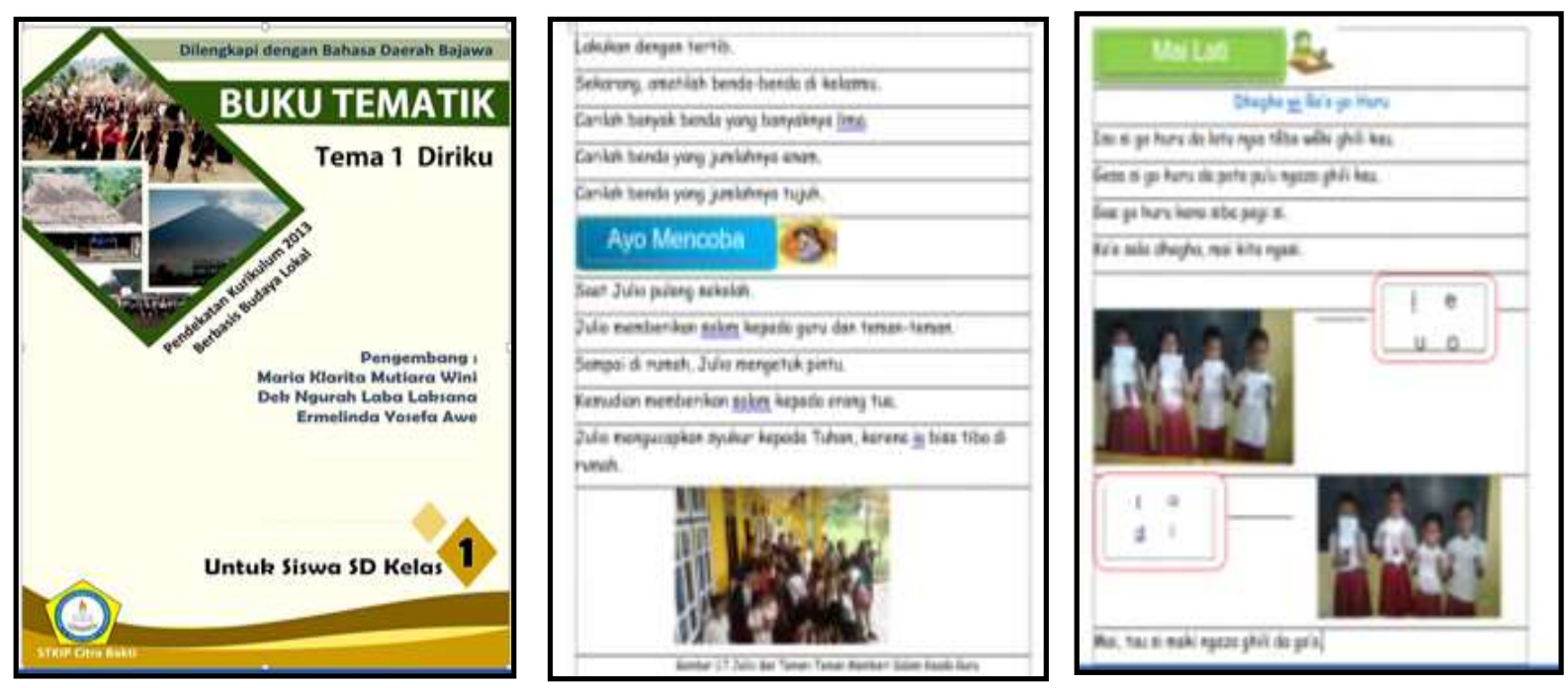

Gambar 1 Tampilan Bagian bagian dari Produk Pengembangan Bahan Ajar

\section{Tahap Implementasi (Implementation)}

Tahap Implementasi I

Peneliti melakukan uji coba produk pada tahap implementasi ini kepada ke empat ahli sebagai validator. Hasil uji coba ini di peroleh berupa masukan dari para ahli adalah sebagai berikut: 1) uji Ahli Materi/ Konten, komentar dan saran yang diberikan sebagai bahan revisi terhadap bahan ajar yang dikembangkan yaitu perhatikan tanda baca, perhatikan keterangan gambar, arti kata bahasa daerah, perhatian tanda centang yang benar, 2) uji Ahli Bahasa Indonesia, komentar dan saran yang diberikan oleh ahli bahasa yaitu memperhatikan tata tulis yang baik dan benar, hubungan kalimat antar paragraf dalam sebuah cerita, penebalan kata dan kalimat, penggunaan tanda baca sesuai dengan EYD, 3) uji Ahli Bahasa Daerah, komentar dan saran yang diberikan oleh ahli bahasa yaitu arti bahasa daerah, keterangan pada gambar, sebaiknya selalu menggunakan tanda baca bahasa daerah Bhajawa yang telah diberikan seperti pada konsonan bh, dh, gh dan pada vokal ada bunyi lemah, bertekanan (a, i, o, u) pada e,'e, ê bunyi lemah, bertekanan dan sahwa, 4) uji Ahli Desain, komentar dan saran yang diberikan oleh ahli desain yaitu sudah sis tematis dan bagus, dan bisa diuji cobakan. 
Pada tahap ini, peneliti melakukan revisi bahan ajar multilingual sesuai dengan komentar dan saran yang diberikan oleh beberapa para ahli kepada peneliti.

\section{Tahap Implementasi II}

Pada tahap ini, peneliti melakukan pengujian dengan memberikan lembar kuisioner kepada para ahli baik ahli konten/ materi, ahli bahasa Indonesia, ahli bahasa daerah dan ahli desain produk. Adapun hasil pengujian dari para ahli adalah sebagai berikut: (1) hasil uji coba ahli konten/ materi mendapatkan rata-rata 4,2 dan berada pada kateori sangat baik, (2) hasil uji coba ahli bahasa Indonesia mendapatkan rata-rata 4,8 dan berada pada kategori sangat baik, (3) hasil uji coba ahli bahasa daerah mendapatkan rata-rata 3,7 dan berada pada kategori baik, (4) hasil uji coba ahli desain mendapatkan rata-rata 3,90 dan berada pada kategori baik.

\section{Tahap Evaluasi (Evaluation)}

Setelah melakukan uji coba dengan memberikan lembar kuisioner kepada para ahli. Peneliti melakukan revisi berdasarkan komentar dari para ahli, dengan tujuan untuk mengetahui kelayakan penggunaa bahan ajar multilingual.

Sesudah melakukan pengujian kepada beberapa para ahli dan mendapatkan penilaian dan revisi pada bahan ajar yang di kembangkan dapat memperoleh bahan ajar yang layak untuk diuji cobakan. Produk ini menghasilkan bahan ajar multilingual berbasis konten dan konteks budaya lokal etnis Ngada yang menggunakan dua bahasa antara lain bahasa daerah Bhajawa tepatnya bahasa daerah Kecamatan Golewa dan bahasa Indonesia. Pada tahap pengujian produk peneliti memberikan lembar kuisioner kepada para ahli untuk diberi penilaian dengan skala 1-5. Adapun keunggulan dari produk yang dikembangkan yaitu produk yang dikembangkan dilengkapi dengan dua bahasa yaitu bahasa Indonesia dan bahasa daerah Bajawa khususnya bahasa daerah Kecamatan Golewa, produk yang dikembangkan berbasis budaya lokal Ngada, produk yang dikembangkan dilengkapi dengan gambar-gambar yang kontekstual.

\section{Pembahasan}

Bahan ajar adalah seperangkat materi yang disusun secara sistematis baik tertulis maupun tidak tertulis sehingga tercipta lingkungan atau suasana yang memungkinkan siswa belajar (Kemendikbud, 2013). Ada beberapa karakteristik bahan ajar cetak antara lain: 1) harus mampu membelajarkan sendiri para siswa (self-instructional) artinya bahan ajar cetak harus mempunyai kemampuan menjelaskan yang sejelas-jelasnya untuk membantu siswa dalam proses pembelajaran, baik bimbingan guru maupun secara mandiri, 2) bersifat lengkap (self-contained) artinya memuat hal-hal yang sangat diperlukan dalam proses pembelajaran, 3) mampu membelajarkan peserta didik (self-instructional material) artinya dalam bahan pembelajaran cetak harus mampu memicu siswa untuk aktif dalam proses belajarnya bahkan membelajarkan siswa untuk dapat menilai kemampuan belajarnya sendiri.

.Bahan ajar ini sudah sesuai dengan apa yang dipaparkan oleh Mulyasa (2015) yang telah diuraikan sebelumnya. (1) bahan tertulis biasanya menampilkan daftar isi, sehingga memudahkan guru untuk menunjukkan kepada siswa bagian mana yeng sedang dipelajari, (2) biaya penggandaan relatif sedikit, (3) bahan tertulis cepat digunakan dan dapat dipindahpindahkan secara mudah, (4) bahan ajar yang baik akan dapat memotivasi pembaca untuk melakukan aktivitas, seperti menandai, mencatat, membuat sketsa.

Menurut Alexon (2010: 45) (dalam Dopo, 2019) pembelajaran berbasis budaya merupakan pembelajaran yang mengintegrasikan budaya dalam proses pembelajaran serta salah satu bentuknya adalah menekankan belajar dengan budaya. Belajar dengan budaya menjadikan siswa tidak terasing dari budaya lokalnya serta meningkatkan apresiasi siswa terhadap budaya lokal. Selain itu Surtano (2012) menjelaskan bahwa pembelajaran berbasis 
budaya sangat bermanfaat bagi pemaknaan proses dan hasil belajar yang kontekstual dan bahan apresiasi untuk memahami konsep ilmu pengetahuan dalam budaya lokal (etnis) yang dimiliki.

Pembelajaran multilingual adalah pembelajaran yang menggunakan dua bahasa atau lebih dari dua bahasa sebagai pengantar pembelajaran. Pembelajaran tematik dalam bahasa Indonesia dan bahasa daerah Bajawa adalah pembelajaran yang materi pembelajarannya, proses belajar mengajar, dan penilainnya disampaikan dalam bahasa Indonesia dan bahasa daerah. Jadi pembelajaran multilingual merupakan jalan yang digunakan guru untuk menciptakan suasana yang memungkinkan siswa belajar dengan menggunakan pengantar dua bahasa.

Dalam penelitian ini telah dilakukan uji coba oleh peneliti kepada para ahli untuk mengembangkan bahan ajar cetak multilingual yang dilakukan melalui beberapa tahapan dengan menggunakan model ADDIE. Pengembangan bahan ajar ini hanya terbatas pada uji ahli saja dan penelitian pengembangan ini dilakukan di Kecamatan Golewa dengan lama penelitian sejak tanggal 8 Juli 2020 sampai 8 Agustus 2020. Bahan ajar ini mengembangkan dua bahasa yaitu bahasa Indonesia dan bahasa daerah Bajawa. Pada tahap pengembangan dikembangkan jaringan tema, sub-sub tema dan berbagai kegiatan pembelajaran.

Pada tahap pengembangan jaringan tema dalam bahan ajar multilingual memuat kompetensi dasar yang harus siswa capai dalam pembelajaran, yang dibuat dalam bentuk bagan. Jaringan tema dibuat hanya untuk satu tema saja yaitu "Diriku". Sub-sub tema yang ada dalam bahan ajar pengambangan ini berfungsi agar mengetahui kokmpetensi yang ada dalam setiap pembelajaran baik dari pembelajaran 1 sampai dengan pembelajaran 6. Kegiatan pembelajaran berisi tentang apa yang harus dilakukan peserta didik selama proses belajar mengajar dan kegiatan yang harus dilakukan di rumah bersama orang tua. Ada berbagai kegiatan pembelajaran antara lain ayo membaca, ayo menulis, ayo berkreasi, ayo berlatih, ayo menari, ayo bermain peran dan kegiatan bersama orang tua.

Dengan adanya bahan ajar multilingual berbasis budaya lokal diharapkan dapat membantu guru dan peserta didik dalam melakukan proses belajar mengajar untuk lebih mengenal budaya lokal setempat. Bahan ajar ini dikemas sebagai sumber belajar yang dapat meringankan siswa dalam mencerna pembelajaran dan meringankan guru dalam meneruskan pembelajaran. Diharapkan bahan ajar multilingual ini dapat mencapai tujuan pembelajaran dan menambah kualitas dalam suatu pembelajaran (Abdillah, 2010) (dalam Seso, 2018). Kajian budaya lokal harus menyatu dalam pembelajaran sebagai upaya untuk menambah kualitas pembelajaran. Pembelajaran yang dilakukan dengan mengintegrasikan konten dan konteks budaya lokal mendapat respon positif dari siswa Riwu, dkk (2018) dalam penelitian ditemukan bahwa bahan ajar bermuatan multimedia berdasarkan konten dan konteks budaya lokal mendapat kategori sangat baik, sehingga layak digunakan pada siswa sekolah dasar.

Bahan ajar yang dikembangkan ini memeiliki 6 bagian yang paling utama yaitu: 1) kover, 2) daftar isi, 3) jaringan tema, 4) isi buku, dan 5) daftar pustaka. Produk yang dihasilkan telah dinilai oleh ahli sebagai validator. Dari angket yang dinilai diperoleh masukan-masukan mengenai bahan ajar yang telah dikembangkan. Dari masukan-masukan tersebut peneliti gunakan sebagai bahan untuk merevisi produk. Bahan ajar yang telah dikembangkan adalah bahan ajar cetak.

Beberapa penelitian tentang bahan ajar berbasis budaya lokal khususnya dalam pembelajaran sekolah dasar telah banyak dilakukan. Budaya Ngada secara konten dan konteks dapat diintegrasikan ke dalam materi pembelajaran sekolah dasar (Baka dkk, 2018). Selain itu, Laksana, dkk (2017); Laksana dkk, (2018); Seso dkk, (2018); dan Dopo (2019) juga telah mengembangjan produk bahan ajar pada kelas IV sekolah dasar. Pengembangan tersebut mendapatkan penilaian dalam kategori baik dan sangat baik. Hal ini berarti produk bahan ajar yang dikembangkan, layak digunakan dalam pembelajaran di sekolah dasar. 


\section{KESIMPULAN}

Berdasarkan bahan ajar multilingual berbasis konten dan konteks budaya lokal etnis Ngada pada tema diriku untuk siswa kelas I sekolah dasar dan penjelasan hasil penelitian yang sudah dibahas di bab sebelumnya, maka dapat disimpulkan sebagai berikut: 1) Penelitian yang dilakukan menghasilkan/membuahkan produk bahan ajar multilingual berbasis konten dan konteks budaya lokal etnis Ngada pada tema diriku yang sesuai dengan karakteristik siswa kelas I sekolah dasar. Setelah mendapatkan penilaian dari para ahli yang diberikan berupa lembar kuisioner mencapai hasil yang sangat baik. 2) Berdasarkan hasil uji coba ahli materi/ konten kualitas/mutu produk mendapatkan kriteria "sangat baik" dengan skor rata-rata 4,2. Berdasarkan hasil uji coba ahli bahasa Indonesia kualitas/ mutu produk mendapatkan kriteria "sangat baik" dengan skor rata-rata 4,8. Berdasarkan hasil uji coba ahli bahasa daerah kualitas/ mutu produk mendapatkan kriteria"baik" dengan skor rata-rata 3,7. Berdasarkan hasil uji coba ahli desain kualitas/ mutu produk mendapatkan kriteria“baik" dengan skor ratarata 3,90 .

\section{DAFTAR PUSTAKA}

Anglada, D. (2007). An Introduction to Instructional Design: Utilizing a Basic Design Model. http://www.pace.sdu/ctlt/newsletter. Diakses pada tanggal 05 Juni 2019

Baka, N.A., Laksana, D.N.L., \& Dhiu, K.D. (2018). Konten dan Konteks Budaya Lokal Ngada Sebagai Bahan Ajar Tematik di Sekolah Dasar. Journal of Education Technology $2(2), 46-55$

BSNP. (2006). Standar Isi. Jakarta: Badan Standar Nasional Pendidikan.

Dopo, T. (2019). Pengembangan Bahan Ajar Elektronik Multimedia Berbasis Budaya Lokal Ngada Pada Tema Daerah Tempat Tinggalku Untuk Siswa Sekolah Dasar Kelas IV.Skripsi. (tidak diterbitkan). Ngada: STKIP Citra Bakti.

Elvianti, E. (2015). Pengembangan Buku Ajar Berbasis Budaya Daerah Pada Sub Tema Keberagaman Makhluk Hidup di Lingkunganku Kelas IV Mi Al Ma'arif 09 Singosari. Jurnal. https://www.sites.google.com>artikelpendidikan.pdf. Diakses pada tanggal 21 Juni 2019

Laksana D. N. L, Kurniawan P. A. W, \& Niftalia Irama. (2016). Pengembangan Bahan Ajar Tematik SD Kelas IV Berbasis Kearifan Lokal Masyarakat Ngada. Jurnal İmiah Pendidikan Citra Bakti, 3 (1), 1-10

Laksana, D.N.L. (2017). The Effectiveness of Inquiry Based Learning For Natural Science Learning In Elementary School. Journal of Education Technology, 1 (1), 1-5

Laksana. D.N.L, Dasna.I. W, \& Sudatha. I. G. W. (2017). Desain dan model pembelajaran inovatif dan interaktif. Jakarta: Universitas Terbuka

Undang-undang RI No. 20 Tahun 2003. 2012. Sistem Pendidikan Nasional. Bandung: Citra Umbara. 